\title{
PENGARUH LINGKUNGAN KERJA TERHADAP PRESTASI KERJA KARYAWAN PADA PT. PLN (PERSERO) CABANG KENDARI
}

\author{
Muhammad Erman Bani \\ STMIK Catur Sakti Kendari,
}

\begin{abstract}
ABSTRAK
Tujuan penelitian ini adalah untuk mengetahui Pengaruh Lingkungan Kerja Terhadap Prestasi Kerja Karyawan Pada PT. PLN (Persero) Cabang Kendari. Sampel penelitian ini ditetapkan secara purposive sampling dimana jumlah karyawan yang diambil sebanyak 28 karyawan dari 56 karyawan secara keseluruhan.
\end{abstract}

Hasil penelitian dengan menggunakan alat analisis regresi linear berganda menunjukkan bahwa secara simultan seluruh faktor Lingkungan Kerja (Sarana kerja, Tata ruang, Hubungan antar karyawan, Kenyamanan, dan Keamanan) mempunyai pengaruh yang signifikan terhadap Prestasi Kerja Karyawan Pada PT. PLN (Persero) Cabang Kendari. Hal ini ditujukkan dengan nilai ( $\left.\mathrm{F}_{\text {signifikan }} 0,000\right)$ lebih kecil dari nilai $\alpha 0,05\left(\mathrm{~F}_{\text {signifikan }}<\alpha 0,05\right)$, sedangkan secara parsial dari kelima factor lingkungan kerja mempunyai pengaruh secara signifikan terhadap prestasi kerja karyawan PT. PLN (Persero) Cabang Kendari masingmasing untuk faktor sarana kerja nilai t signifikan $0,000<\alpha 0,05$, hubungan antar karyawan nilai t signifikan $0,018<\alpha 0,05$, untuk faktor tata ruang nilai $\mathrm{t}$ signifikan $0,000<\alpha 0,05$, hubungan antar karyawan nilai t signifikan $0,019<\alpha 0,05$, kenyamanan nilai $\mathrm{t}$ signifikan $0,027<\alpha 0,05$ dan keamanan nilai t signifikan 0,042< $<0,05$. Berdasarkan hasil penelitian tersebut maka disarankan agar lingkungan kerja yang memiliki hubungan yang positif terhadap prestasi kerja karyawan dipertahankan oleh PT. PLN (Persero) Cabang Kendari.

Kata Kunci : Lingkungan Kerja dan Prestasi Kerja

\section{A. PENDAHULUAN}

Sumber daya manusia adalah salah satu unsur yang terpenting dalam suatu organisasi/perusahaan yang merupakan tempat manusia bekerja sama, berkumpul untuk mencapai tujuan tertentu. Semakin banyak individu yang terlibat maka semakin kompleks pula organisasi itu dalam mencapai tujuan secara efektif dan efisien.

Sumberdaya manusia dalam suatu organisasi maupun swasta akan berkurang 
secara efektif dan efisien apabila digerakkan dan dikendalikan oleh para tenaga kerja atau karyawan yang kurang memiliki prestasi kerja atau kemampuan.

Prestasi kerja seseorang karyawan didalam suatu organisasi tidak hanya tercermin pada kemampuannya dalam kaitannya dengan lingkungan kerja berbagai penelitian menunjukkan masih ada perusahaan yang tidak pernah atau kurang memperhatikan lingkungan kerja.

\section{Lingkungan kerja merupakan} segala yang ada disekitar para karyawan dapa mempengaruhi dirinya dalam menjalankan tugas-tugas yang dibebankan kepadanya. Dalam hal ini lingkungan kerja berhubungan dengan lingkungan fisik, dimana karyawan dapat memanfaatkan setiap sarana yang ada secara optimal. Lingkungan kerja fisik sebagai sasaran fisik perusahaan akan menjadi hambatan terhadap pekerjaan bia semua sara yang diperlukan tidak dapat menjembatani kerja atau berfungsi sebagaimana mestinya. Sebaliknya lingkungan kerja fisik akan menjembatani penunjang kelancaran pelaksanaan pekerjaan apabila berfungsi dengan baik. Menurut Alex Nitisemito S. (1996:109).

Menurut Marwan Asri (1986 : 73) Lingkungan kerja adalah suatu kondisi dimana didalamnya para karyawan melaksanakan suatu aktivitas. Kondisi tersebut dapat berupa material maupun kondisi phisikologis, seperti keadaan sarana kerja , pengaturan ruangan, keharmonisan hubungan antar karyawan. Dalam hal ini lingkungan adalah berhubungan dengan lingkungan fisik sehingga keterampilan manusia harus mampu memanfaatkan setiap sarana yang ada secara optimal.

Seorang karyawan mampu bekerja dan menunjukkan hasil karyanya yang baik terhadap penyelesaian tugas-tugasnya serta dapat menyelesaikannya berdasarkan target waktu yang diharapkan, karena itu diharapkan pimpinan dalam memberikan tugas maupun jabatan kepada karyawan harus dilandasi dengan penilaian yang objektif berdasarkan atas keahlian dan kecakapannya sehingga diharapkan dapat meningkatkan prestasi kerjanya.

Dukungan lingkungan kerja yang menyenangkan menyebabkan karyawan manghasilkan karya yang lebih baik. Bila semangat kerja karyawan menurun maka menimbulkan akibat antara lain proses produksi terganggu dan akibatnya target produksi takkan tercapai. Dengan demikian lingkungan kerja yang baik seorang karyawan akan lebih bergairah bekerja dan tugas-tugas yang diberikan kepadanya dapat berkesinambungan sehingga mendorong dalam pengembangan prestasi kerja karyawan yang baik. Hal ini dapat dipahami karena prestasi kerja merupakan titik sentral dan 
motor penggerak bagi tumbuhnya inspirasi, inisiatif dan kreativitas untuk bekerja. Seperti halnya PT. PLN (persero) Cabang Kendari yang bergerak dalam bidang usaha bisnis pelayanan jasa sesuai dengan informasi yang diperoleh bahwa fasilitas fisik yang menbdu fisik yang mendukung kegiatan kerja karyawan sudah cukup memadai untuk dapat digunakan para karyawan sehari-hari.

\section{Peningkatan prestasi kerja} karyawan tidak hanya ditentukan oleh tersedianya fasilitas kerja yang memadai, tetapi dapat pula ditentukan oleh hubungan sesame karyawan tata ruang yang baik dan sebagainya. Tanpa adanya keharmonisan hubungan antar sesame karyawan serta tata ruang yang kurang baik akan menimbulkan kemalasan dalam bekerja sehingga memungkinkan prestasi kerja karyawan menurun. Berkaitan dengan hal tersebut penulis tertarik untuk mengadakan suatu penelitian berkaitan dengan “ Pengaruh Lingkungan Kerja Terhadap Prestasi Kerja Karyawan Pada PT. PLN (Persero) Cabang Kendari”.

\section{B. TINJAUAN PUSTAKA}

\section{Lingkungan Kerja}

\subsection{Pengertian Lingkungan Kerja}

Ada banyak faktor yang bisa mempengaruhi karyawan untuk dapat bekerja lebih baik. Salah satu faktor yang dianggap mempengaruhi proses jalannya kerja yang teratur adalah dengan menciptakan lingkungan kerja yang baik dan menyenangkan. Lingkungan kerja yang baik dan teratur akan menciptakan suasana rasa aman serta menambah gairah kerja bagi karyawan.

Menurut Alex Nitisemito S. (1996:109) lingkungan kerja adalah segala sesuatu yang ada disekitar para karyawan dan dapat mempengaruhi dirinya dalam menjalankan tugas-tugas yang dibebankan kepadanya.

Menurut Marwan Asri (1996:73) mengatakan bahwa lingkungan kerja adalah suatu kondisi dimana didalamnya para karyawan melaksanakan suatu aktivitas. Kondisi tersebut bisa berupa kondisi material maupun kondisi psikologis. Dalam hal ini lingkungan kerja berhubungan dengan lingkungan kerja fisik, sehingga manusia dan keterampilan manusia harus mampu memanfaatkan setiap sarana yang ada secara optimal.

\subsection{Faktor - faktor yang} berpengaruh dalam menciptakan lingkungan kerja yang baik

\section{Karyawan}

Karyawan adalah kekayan utama suatu perusahaan karena keikutsertaan mereka, maka aktivitas perusahaan akan terjadi dimana karyawan yang berperan aktif dalam menetapkan rencana, sistem, proses, dan tujuan yang ingin dicapai oleh organisasi. 
Dalam sistem administrasi dan manajemen menekankan bahwa untuk dapat menciptakan suasana kerja karyawan yang lebih bergairah, maka perlu menciptakan suasana lingkungan kerja yang baik. Keadaan lingkungan kerja sangatlah mempengaruhi para karyawan untuk dapat bekerja dengan baik .

Dalam menciptakan lingkungan kerja yang baik ada beberapa faktor yang perlu diperhatikan :

\section{a. Sarana Kerja}

Sarana merupakan segala sesuatu (bisa berupa syarat atau upaya) yang dipakai sebagai alat media dalam mencapai maksud atau tujuan.

Sarana kerja yang baik, jika didalam suatu ruangan kerja terdapat perlengkapan dan fasilitas yang harus tersedia seperti fasilitas meja, pesawat telepon, buku atau bahan referensi, komputer, printer, rak arsip dan lain-lain untuk membantu dan mempermudah dalam melaksanakan pekerjaan atau tugas yang diberikan sehingga prestasi kerja karyawan meningkat.

\section{b. Tata Ruang}

Tata ruang merupakan penentuan kebutuhan - kebutuhan dalam penggunaan ruang juga merupakan wujud strudtural dan pola pemanfaatan ruang.

Dalam suatu perusahaan hendaknya karyawan yang bekerja mendapat tempat yang cukup untuk melaksanakan pekerjaan atau tugas. Seseorang tidak mungkin dapat bekerja dengan tenang jika tempat yang tersedia tidak dapat memberikan kenyamanan.

Padatnya ruang gerak dan penataan ruangan yang sempit dapat mengurangi prestasi kerja karyawan dalam melakukan aktivitasnya. Dengan demikian penataan ruangan di dalam melaksanakan pekerjaan perlu diperhatikan sehingga karyawan dapat bekerja dengan baik.

c. Hubungan Antar Karyawan

Menurut Margiati (1999 : 73) merupakan suatu keadaan atau hubungan antar karyawan yang ada dalam perusahaan yang dapat menimbulkan perasaan tertekan kepada karyawan yang berakibatkan pada menurunnya gairah kerja karyawan yang pada akhirnya akan berpengaruh pada prestasi kerja karyawan tersebut. Beberapa komponen tersebut antara lain adanya tugas atau tanggung jawab yang berlebihan yang diberikan kepada karyawan, adanya hubungan kurang harmonis dengan supervisor atau pembimbing karyawan dalam melakukan pekerjaan sehari-hari dengan keterbatasan waktu dalam menyelesaikan tugas termasuk kurangnya seorang karyawan dalam mendapatkan tugas dan tanggung jawab dari perusahaan.

d. Kenyamanan 


\section{Kenyamanan \\ merupakan}

perasaan didalam diri kita ketika jauh dari segala hal yang tidak diinginkan. Di dalam suatu perusahaan hendaknya menjaga kebersihan lingkungan sebab kebersihan lingkunga dapat mempengaruhi kesehatan jiwa seseorang. Dapat dibayangkan bila anda bekerja pada suatu tempat yang penuh dengan debu dan bau yang tidak sedap apalagi pekerjaan itu memrlukan konsentrasi yang cukup tinggi. Dengan adanya lingkungan kerja yang bersih karyawan akan merasa nyaman sehingga prestasi kerja karyawan akan meningkat.

\section{e. Keamanan}

Rasa aman bagi karyawan sangat berpengaruh terhadap prestasi kerja dan gairah kerja karyawan . disini yang dimaksud dengan keamanan yaitu jauh dari segala yang tidak diinginkan yang dapat dimasukkan ke dalam lingkungan kerja.

Jika ditempat kerja tidak aman karyawan tersebut akan menjadi gelisah, tidak bisa berkonsentrasi dengan pekerjaannya serta prestasi kerja karyawan tersebut akan mengalami penurunan.

Oleh karena itu sebaiknya suatu perusahaan terus berusaha untuk menciptakan dan mempertahankan suatu keadaan dan suasana aman tersebut dapat dirasakan oleh karyawan agar karyawan tersebut tidak merasa terganggu dalam melaksanakan pekerjaannya dan pekerjaan yang yang diberikan kepada karyawan merasa senang dan betah dalam bekerja.

\section{Pengertian Prestasi Kerja}

Menurut Agus Dharma (1985

:1) prestasi kerja adalah sesuatu yang dikerjakan atau produk jasa-jasa yang diberikan atau yang dihasilkan oleh seseorang atau sekelompok orang.

Mangkunegara (2002) prestasi kerja adalah hasil kerja secara kualitas dan kuantitas yang dicapai oleh seseorang karyawan dalam melaksanakan tugasnya sesuai dengan tanggung jawab yang diberikan kepadanya.

Hasibuan Malayu (2000) mengatakan prestasi kerja adalah suatu hasil kerja yang dicapai oleh seseorang karyawan dalam melaksanakan tugasnya sesuai dengan tanggung jawab yang diberikan kepadanya.

Menurut Sondang P. Siagian (2004 : 227 - 228) suatu system penilaian prestasi kerja yang baik sangat bermanfaat untuk berbagai kepentingan seperti :

1. Mendorong peningkatan prestasi kerja

2. Sebagai bahan pengambil keputusan dalam pemberian imbalan

3. Untuk kepentingan mutasi pegawai

4. Guna menyusun program pendidikan dan pelatihan

5. Membantu para pegawai menentukan rencana karirnya dan menyusun program pengembangan karir. 


\section{Menurut Edwin B. Flippo}

dalam Moh. As'ad (1999 : 250) mengemukakan indikator prestasi kerja terdiri dari :

1. Kualitas kerja (quality of work) yaitu kemampuan karyawan untuk mengambil keputusan dan melaksanakan suatu tindakan yang diperlukan dalam melaksanakan tugas tanpa menunggu perintah.
2. Kuantitas kerja (quantity of work) yaitu karyawan harus berupaya dengan sekuat tenaga untuk mencapai hasil kerja yang sesuai dengan target.

3. Ketangguhan yaitu kemampuan atau kesanggupan karyawan dalam menyelesaikan pekerjaan dengan sebaik-baiknya dan tepat waktu serta keberaniannya mengambil resiko atas keputusan yang diambil.

\section{Kerangka Pikir}

\section{Skema 2 Kerangka Pikir}

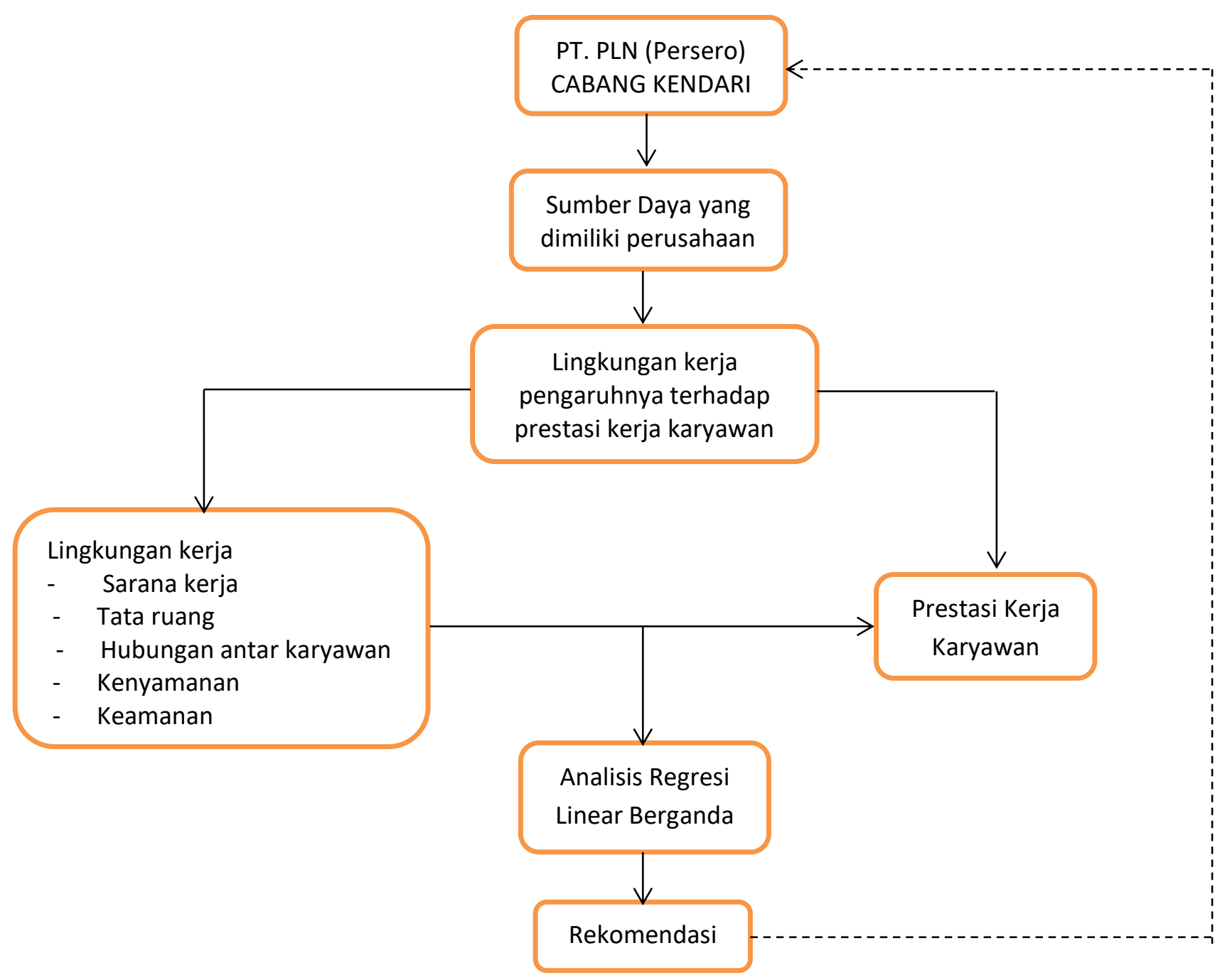




\section{SULTRA Journal of $E_{\text {conomic and Business (SJEB) }}$ \\ Volume 1 Nomor 3, April 2021 \\ ISSN 2716-1781}

Sarana publikasi bagi para akademisi, peneliti, dan praktisi di bidang Ilmu Ekonomi Dan Bisnis dalam menerbitkan artikel hasil penelitian maupun artikel telaah konseptual.

\section{METODE PENELITIAN}

\section{Populasi dan sampel}

\section{Populasi}

Pengertian populasi menurut Nazir (2003:271) populasi adalah kumpulan dari individu dengan kualitas serta ciri-ciri yang telah ditetapkan. Populasi pada penelitian ini adalah seluruh karyawan tetap PT.PLN (Persero) Cabang Kendari berjumlah 56 karyawan.

\section{Sampel}

Pengertian Sampel menurut Nazir (2003:271) Sampel adalah bagian dari populasi atau sejumlah subjek penelitian sebagai wakil dari populasi yang dituju. Adapun penarikan sampel pada penelitian ini ditentukan secara sengaja (purposive sampling) sebanyak 28 karyawan didasarkan pada pendapat yang di kemukakan oleh Suharsimi A. (1986:107) karena dianggap telah mewakili keseluruhan jumlah populasi.

\section{Jenis dan Sumber Data}

\section{Jenis Data}

1. Data Kualitatif adalah data yang berupa pernyataan pernyataan maupun pendapat.

2. Data Kuantitatif adalah data yang berupa angka-angka.

\section{Sumber Data}

1. Data Primer

Data Primer yaitu data yang diperoleh langsung dari para karyawan yang

dijadikan responden

melalui penyebaran kuesioner meliputi sarana kerja, tata ruang, hubungan antar karyawan, kenyamanan, keamanan maupun tanggapan terhadap penyelesaian pekerjaan pada PT. PLN (Persero) Cabang Kendari.

2. Data Sekunder

Data Sekunder yaitu data yang diperoleh secara tidak langsung untuk mendapatkan

informasi/keterangan dari objek yang diteliti. Data ini diperoleh melalui laporan, dokumen-dokumen literature dan bacaan bacaan yang berhubungan dengan penelitian pada PT. PLN (Persero) Cabang Kendari.

\section{Metode Pengumpulan Data}

Untuk memperoleh data maka penulis menggunakan metode pengumpulan data sebagai berikut :

1. Kuesioner yaitu teknik pengumpulan data dengan menggunakan daftar pertanyaan yang diberikan kepeda 


\section{SULTRA Journal of Economic and Business (SJEB) \\ Volume 1 Nomor 3, April 2021 \\ ISSN 2716-1781}

Sarana publikasi bagi para akademisi, peneliti, dan praktisi di bidang Ilmu Ekonomi Dan Bisnis dalam menerbitkan artikel hasil penelitian maupun artikel telaah konseptual.

responden untuk mengukur variabel-variabel yang diteliti.

2. Observasi yaitu mengadakan pengamatan langsung kegiatankegiatan yang berhubungan dengan masalah yang akan diteliti.

3. Dokumentasi yaitu mengambil data yang telah didokumentasikan oleh perusahaan yang ada relevansinya dengan penelitian ini.

4. Interview yaitu mengadakan wawancara langsung terhadap responden pada objek penelitian.

4. Metode Pengolahan Data

Pengolahan data dilakukan dengan cara tabulasi yaitu memasukkan data kedalam tabel untuk selanjutnya menjadi bahan analisis.

5. Pengujian Validitas dan Realibilitas Instrumen

\subsection{Uji Validitas}

Suatu instrument dapat dikatakan valid jika dapat mengukur apa yang seharusnya diukur. Dengan kata lain uji validitas dimaksudkan untuk mengetahui tingkat ketepatan alat ukur (instrument) yang digunakan dalam mengukur variabel yang akan diukur. Untuk menghasilkan indeks atau angka koefisien validitas akan digunakan program SPSS versi 16.0 suatu instrument dikatakan valid jika telah memenuhi sebesar 0,3 (Solimun, $2002: 26)$.

\subsection{Uji Reliabilitas}

Uji Reliabilitas instrument dimaksudkan untuk mengetahui tingkat kehandalan atau kesalihan suatu alat ukur yang digunakan dalam mengukur variabel yang akan diukur. Uji reliabilitas instrument dalam penelitian ini digunakan taraf kepercayaan (significance level) $\alpha=0,05$. Uji reliabilitas intrumen digunakan model analisis korelasi product moment person. Sedangkan untuk menghasilkan indeks atau angka koefisien reliabilitas akan digunakan program SPSS versi 16,0. Suatu instrument dikatakan reliabel jika telah memenuhi syarat minimal sebesar 0,6 (malhotra, 1999 : 282).

6. Peralatan Analisis

Untuk memecahkan masalah atau menguji hipotesisi digunakan analisis regresi berganda. Analisis regresi linear berganda digunakan untuk menghitung seberapa besar pengaruh lingkungan kerja terhadap prestasi kerja karyawan pada PT. PLN (Petsero) Cabang Kendari. Regresi linear berganda sebagaiman yang dikemukakan oleh Sudjana (1996: 135) adalah sebagai berikut : 


$$
\begin{aligned}
& Y=a+b_{1} X_{1}+b_{2} X_{2}+b_{3} X_{3}+b_{4} X_{4} \\
& \left.+b_{5} X_{5} \text { (Sudjana, } 1996: 135\right)
\end{aligned}
$$

Keterangan:

$$
\begin{aligned}
& \mathrm{Y}=\text { Prestasi Kerja Karyawan } \\
& \mathrm{a} \quad=\text { Bilangan Konstanta }( \\
& \text { Intercept }) \\
& \mathrm{X}_{1} \quad=\text { Kondisi sarana kerja } \\
& \mathrm{X}_{2} \quad=\text { Pengaturan ruangan } \\
& \mathrm{X}_{3} \quad=\quad \text { Hubungan antar } \\
& \text { karyawan } \\
& \mathrm{X} 4 \quad=\text { Kenyamanan } \\
& \mathrm{X} 5 \quad=\text { Keamanan }
\end{aligned}
$$

$\mathrm{b}_{1}, \mathrm{~b}_{2}, \mathrm{~b}_{3}, \mathrm{~b}_{4}, \mathrm{~b}_{5}$ : Koefisien Regresi

untuk menguji pengaruh secara simultan digunakan uji $\mathrm{F}$. jika uji $\mathrm{F}$ signifikan $<\alpha=0,05$ berarti secara simultan terdapat pengaruh yang signifikan antara variabel bebas $(\mathrm{X})$ dengan variabel terikat (Y). sebaliknya jika nilai $\mathrm{F}$ signifikan > $\alpha=0,05$ berarti secara simultan tidak terdapat pengaruh yang signifikan antara variabel bebas (X) dengan variabel terikat (Y). disamping itu pula digunakan uji $\mathrm{t}$ dengan pengujian jika $\mathrm{t}$ signifikan $<\alpha=0,05$ berarti terdapat pengaruh yang signifikan secara parsial antara masaing-masing variabel $(\mathrm{X})$ terhadap variabel $(\mathrm{Y})$ sebaliknya jika nilai t signifikan > $\alpha=0,05$ berarti tidak ada pengaruh yang signifikan secara parsial antara masing-masing variabel $\mathrm{X}$ terhadap variabel $\mathrm{Y}$.

7. Definisi operasional variabel

Definisi operasional adalah unsur penelitian yang memberitahukan bagaimana cara mengatur suatu variabel. Menurut Nazir (2003 :126) definisi operasional adalah suatu definisi yang diberikan kepada suatu variabel atau konstrak dengan cara memberikan arti, atau menspesifikasikan kegiatan ataupun memberikan suatu operasional yang diperlukan untuk menunjukkan konstrak atau variabel tersebut.

1. Lingkungan Kerja (X) adalah persepsi responden atas lingkungan kerja yang berada disekitar para karyawan yang dapat membantu menjalankan segala kegiatan yang akan dilaksanakan, meliputi fsktor sarana kerja , pengaturan ruangan

keharmonisan/hubungan kerja, karyawan, keamanan, dan kebersihan yang diukur dengan menggunakan skala likert.

2. Prestasi Kerja (Y) adalah tanggapan atau penilaian pimpinan terhadap prestasi kerja karyawan dalam 
melaksanakan tugasnya yang

berhubungan dengan

kualitas kerja. (2) kuantitas

kerja. (3) Ketangguhan yang

dikur dengan menggunakan

skala likert.

\section{HASIL PENELITIAN DAN PEMBAHASAN}

\section{Hasil Analisis Statistik}

Berdasarkan hasil analisis statistik mengenai pengaruh antara lingkungan kerja dengan prestasi kerja karyawan pada PT. PLN (Persero) Cabang Kendari yang diolah dengan bantuan program "statistical Package for the Social Sciences “ (SPSS) diperoleh hasil yang ditunjukkan oleh tabel berikut :

Tabel . Rekapitulasi Hasil Analisis Regresi Berganda

\begin{tabular}{|l|l|c|c|c|}
\hline No & Variabel Bebas & Koefisien Regresi $(\beta)$ & $\mathrm{T}$ & Sig t \\
\hline 1 & Sarana Kerja $\left(\mathrm{X}_{1}\right)$ & 0,171 & 2,546 & 0,018 \\
2 & Tata Ruang $\left(\mathrm{X}_{2}\right)$ & 0,328 & 4,113 & 0,000 \\
3 & Hubungan Antar Karyawan $\left(\mathrm{X}_{3}\right)$ & 0,186 & 2,530 & 0,019 \\
4 & Kenyamanan $\left(\mathrm{X}_{4}\right)$ & 0,225 & 2,372 & 0,027 \\
5 & Keamanan $\left(\mathrm{X}_{5}\right)$ & 0,143 & 2,157 & 0,042 \\
6 & Konstanta (a) & $-0,649$ & \\
& Koefisien Korelasi (R) & 0,994 & \\
& Koefisien Determinasi (R square) & 0,988 & \\
& Fhitung & 355,323 & & \\
& Probabilitas Simultan & 0,000 & \\
\hline
\end{tabular}

Berdasarkan data yang dianalisis, maka diperoleh persamaan fungsi sebagai berikut :

$Y=-0,469+0,171 X_{1}+0,328$

$X_{2}+0,186 X_{3}+0,225 X_{4}+$

\section{$0,143 X_{5}$}

1. Koefisien korelasi (R) sebesar 0,994 , artinya hubungan antara variabel - variabel independent $\left(\mathrm{X}_{1}\right.$, $\left.\mathrm{X}_{2}, \quad \mathrm{X}_{3}, \quad \mathrm{X}_{4}, \quad \mathrm{X}_{5}\right)$ dan dependen (Y) memiliki keeratan hubungan sebesar $99,4 \%$. Korelasi antara variabel depeneden den independent bersifat positif. Artinya, jika nilai $\mathrm{X}$ naik maka akan direspon dengan kenaikan nilai Y. 
2. Koefisien Determinasi $\left(\mathrm{R}^{2}\right)$ sebesar 0,998 artinya bahwa $98,8 \%$ prestasi kerja karyawan dipengaruhi oleh lingkungan kerja karyawan yang didasarkan pada sarana kerja , tata ruang, hubungan antar karyawan, kenyamanan, dan keamanan.

3. Fhitung digunakan untuk menguji apakah model persamaan $\mathrm{Y}=\mathrm{a}+\mathrm{b}_{1} \mathrm{X}_{1}+$ $b_{2} X_{2}+b_{3} X_{3}+b_{4} X_{4}+b_{5} X_{5}$ yang diajukan dapat diterima atau tidak. Apabila nilai $F_{\text {hitung }}=355,323$ dengan nilai probabilitas < a 0,05 maka model yang digunakan dapat diterima. Berdasarkan tabel terlihat bahwa nilai $F_{\text {hitung }}=$ 355,323 dengan nilai probalitita $=0,000<\alpha 0,05$ sehingga dapat dikatakan model yang digunakan sudah tepat dan dapat diterima.

\section{Pengujian Hipotesis}

\subsection{Uji Simultan (Uji F)}

Untuk dapat mengetahui tingkat pengaruh antara variabel bebas $\left(\mathrm{X}_{1}, \mathrm{X}_{2}, \mathrm{X}_{3}\right.$, $\mathrm{X}_{4}, \mathrm{X}_{5}$ ) terhadap variabel terikat (Y) maka dilakukan

Uji F dimana hasil penelitian ini dapat dilakukan dengan membandingkan nilai $F$ signifikan dengan nilai $\alpha$ 0,05 dengan syarat bahwa jika nilai $\mathrm{F}$ signifikan $<\alpha$ 0,05 berarti bahwa secara simultan terdapat pengaruh yang signifikan antara variabel bebas $(\mathrm{X})$ denga variabel terikat $(\mathrm{Y})$.

Berdasarkan hasil analisis dalam penelitian ini, diperoleh nilai $\mathrm{F}$ signifikan sebesar 0,000 yang berarti bahwa secara simultan variabel lingkungan kerja yang terdiri dari variabel sarana kerja (X1), tata ruang $\mathrm{X}_{2}$, hubungan antar karyawan $\mathrm{X}_{3}$, kenyamanan $\mathrm{X}_{4}, \quad$ keamanan $\mathrm{X}_{5}$. Berpengaruh secara signifikan terhadap prestasi kerja karyawan pada PT. PLN (Persero) Cabang Kendari.

\subsection{Uji Parsial ( Uji t)}

Untuk mengetahui tingkat keberadaan masing-masing variabel lingkungan kerja $\left(\begin{array}{lllll}X_{1}, & X_{2}, & X_{3}, & X_{4}, & X_{5}\end{array}\right)$ 


\section{SULTRA Journal of Economic and Business (SJEB) \\ Volume 1 Nomor 3, April 2021 \\ ISSN 2716-1781}

Sarana publikasi bagi para akademisi, peneliti, dan praktisi di bidang Ilmu Ekonomi Dan Bisnis dalam menerbitkan artikel hasil penelitian maupun artikel telaah konseptual.

terhadap prestasi kerja (Y)

maka dilakukan uji $\mathrm{t}$,

dengan kriteria pengujian

jika t signifikan $<\alpha 0,05$

berarti terdapat pengaruh

yang signifikan secara

parsial antara masing-

masing variabel $\mathrm{X}$ terhadap

variabel $\mathrm{Y}$ dan sebaliknya

jika nilai $\mathrm{t}$ signifikan $>\alpha$

0,05 maka berarti tidak

ada pengaruh yang

signifikan secara parsial

antara masing-masing

variabel $\mathrm{X}$ terhadap

variabel Y. Hasil uji Parsial

masing -masing variabel $\mathrm{X}$

adalah sebagai berikut :

1. Pengaruh sarana kerja $\left(\mathrm{X}_{1}\right)$ tarhadap prestasi kerja karyawan (Y)

Berdasarkan hasil

analisis uji $\mathrm{t}$ diperoleh

nilai t signifikan untuk variabel $\mathrm{X}_{1}$ sebesar 0,018. Nilai ini menunjukkan bahwa $\mathrm{t}$ signifikan $0,018<\alpha$ 0,05 ini berarti bahwa variabel sarana kerja berpengaruh secara signifikan terhadap prestasi kerja karyawan dalam penelitian ini.
2. Pengaruh tata ruang $\left(\mathrm{X}_{2}\right)$ terhadap prestasi kerja karyawan (Y)

Berdasarkan hasil analisis uji $\mathrm{t}$ diperoleh nilai $\mathrm{t}$ signifikan untuk variabel $\mathrm{X}_{2} \quad$ sebesar 0,000. Nilai ini menunjukkan bahwa $\mathrm{t}$ signifikan untuk 0,000 $<\alpha 0,05 \quad$ ini berarti bahwa variabel sarana kerja berpengaruh secara signifikan terhadap prestasi kerja karyawan dalam penelitian ini.

3. Pengaruh hubungan antar karyawan $\left(\mathrm{X}_{3}\right)$ terhadap prestasi kerja karyawan (Y)

Berdasarkan hasil analisis uji $\mathrm{t}$ diperoleh nilai t signifikan untuk variabel $\mathrm{X}_{3} \quad$ sebesar 0,019. Nilai ini menunjukkan bahwa $\mathrm{t}$ signifikan $0,019<\alpha$ 0,05 . Nilai ini berarti bahwa variabel hubungan antar karyawan berpengaruh secara signifikan terhadap prestasi kerja 
karyawan (Y) dalam

penelitian ini.

4. Pengaruh kenyamanan $\left(\mathrm{X}_{4}\right)$ terhadap prestasi kerja karyawan (Y)

Berdasarkan hasil analisis uji t diperoleh nilai $\mathrm{t}$ signifikan untuk variabel $\mathrm{X}_{4} \quad$ sebesar 0,027. Nilai ini menunjukkan bahwa $\mathrm{t}$ signifikan $0,027<\alpha$ 0,05 . Nilai ini berarti bahwa variabel kenyamanan berpengaruh secara signifikan terhadap prestasi kerja karyawan (Y) dalam penelitian ini.

5. Pengaruh keamanan $\left(\mathrm{X}_{5}\right)$ terhadap prestasi kerja karyawan (Y)

Berdasarkan hasil analisis uji $\mathrm{t}$ diperoleh nilai $\mathrm{t}$ signifikan untuk variabel $\mathrm{X}_{5} \quad$ sebesar 0,042. Nilai ini menunjukkan bahwa $\mathrm{t}$ signifikan $0,042<\alpha$ 0,05 . Nilai ini berarti bahwa variabel keamanan berpengaruh secara signifikan terhadap prestasi kerja karyawan (Y) dalam penelitian ini.

\section{E. PENUTUP}

Berdasarkan hasil analisis penelitian dan pembahasan data di atas , maka dapat ditarik kesimpulkan sebagai berikut :

1. Secara simultan variabel lingkungan kerja yang meliputi sara kerja, tata ruang, hubungan antar karyawan, kenyamanan, keamanan memiliki hubungan antar pengaruh yang signifikan terhadap prestasi kerja pada PT. PLN (Persero) Cabang Kendari. Hal ini ditunjukkan dengan nilai $\mathrm{F}$ signifikan $0,000<\alpha 0,05$.

2. Secara parsial variabel lingkungan kerja yang meliputi sarana kerja $\left(\mathrm{t}_{\text {sig }} 0,018<\alpha\right.$ $0,05)$, tata ruang $\left(\mathrm{t}_{\text {sig }} 0,000<\alpha\right.$ 0,05), hubungan antar karyawan $\left(\mathrm{t}_{\text {sig }} 0,019<\alpha 0,05\right)$, kenyamanan $\left(\mathrm{t}_{\text {sig }} 0,027<\alpha\right.$ $0,05)$, keamanan $\left(\mathrm{t}_{\text {sig }} 0,042<\alpha\right.$ 0,05), memberikam pengaruh yang signifikan terhadap prestasi kerja karyawan pada PT. PLN (Persero) Cabang Kendari.

3. Koefisien regresi lingkungan kerja yang meliputi tata ruang $\left(\beta_{2}=0,328\right)$ serta kenyamanan $\left(\beta_{4}=0,225\right)$ 
dianggap lebih dominan pengaruhnya terhadap prestasi kerja karyawan pada kantor PT. PLN (Persero) Cabang Kendari.

\section{DAFTAR PUSTAKA}

Achmad Ichsan, 1991. Tata Administrasi Karyawan. Jakarta , Djambatan.

Agus Dharma, 1985. Manajemen

Prestasi Kerja. Jakarta, Ghalia Indonesia.

Alex Nitisemito, 1996. Manajemen Personalia. Jakarta, Ghalia Indonesia.

Arianti, 2003. Pengaruh Kedisiplinan Kerja Terhadap Prestasi kerja Karyawan Pada

\section{Kantor Distrik Navigasi}

kendari. Skripsi Fakultas Ekonomi Unhalu.

Bambang Kusriyanto, 1894. Meningkatkan produktivitas kerja karyawan. Jakarta.

PT. Puspita Binaman

Pressindo.

Bernet Silalahi. 1993. Perencanaan

Pembinaan Tenaga Kerja

Perusahaan.

Yogyakarta : PPM.
Flippo, Edwin B, 1990,

Manajemen Personalia. (Edisi

Terjemahan) Cetak Pertama.

Edisi ke-9 PT. Indeks

Gramedia Jakarta.

Gery Dessler, 2004, Manajemen

Sumber Daya manusia. Cetakan

Pertama. Edisi ke-9

PT. Indeks Gramedia Jakarta.

Gery Dessler, 2005. Manajemen Sumber Daya manusia (Alih Bahasa Eli Tanya,

Penyunting bahasa Budi Supriyanto) Edisi 9 Jakarta. Indeks. Hasan, S. 1991. Ensiklopedia Indonesia. Ikhtiar Baru Indonesia.

Hani Handoko T. 1993. Manajemen Personalia Dan Sumberdaya Manusia.

Yogyakarta, BPFE. UGM.

Hasibuan, Melayu. 2000. Manajemen Sumber daya Manusia. Masagung . Jakarta.

Manullang M, 1981. Manajemen Personalia, Jakarta, Ghalia Indonesia.

Marwan Asri, 1986. Pengelola Karyawan. Yogyakarta, BPFE, UGM.

Margiati L. 1999. Stres Kerja Latar Belakang Penyebab dan Alternatif 


\section{SULTRA Journal of $E$ conomic and Business (SJEB) \\ Volume 1 Nomor 3, April 2021 \\ ISSN 2716-1781}

Sarana publikasi bagi para akademisi, peneliti, dan praktisi di bidang Ilmu Ekonomi Dan Bisnis dalam menerbitkan artikel hasil penelitian maupun artikel telaah konseptual.

Pemecahannya. Jurnal

Masyarakat Kebudayaan dan

Politik. Surabaya:

Fakultas

kesehatan

Masyarakat Universitas Airlangga.

Mangkunegara. 2002 . manajemen

Sumberdaya Manusia Perusahaan.

Penerbit PT.

Remaja Rosdakarya.

Bandung.

Muh. As'ad. 1990. Manajemen

Personalia. Cetak ke 6. Jakarta :

Erlangga.

Nawawi H. Hadari. 2003.

Manajemen Sumber Daya

Manusia. Gadjah Mada

University

Press.

Yogyakarta.

Ranupandojo, 2002. Kinerja

manajemen. Penerbit PT. Gramedia

Pustaka Utama

Jakarta

Setiawan dan Tia Harun Lubis, 1990. Tata Laksana Bengkel dirjen

Pendidikan dan

Kerja. Jakarta. Departemen

pendidikan dan Kebudayaan.

Sarwoto, 1991. Dasar-dasar

Organisasi dan Manajemen.

Jakarta, Cetakan 8, Ghalia

Indonesia.

Simamora, Hendry, 2004.

Manajemen Sumber Daya

Manusia. Cetakan Pertama,
Edisi ke 3 STIE YKPN.

Yogyakarta.

Sondang P. Siagian. 2004.

Manajemen Sumberdaya Manusia,

Edisi 1, Cetakan 11.

Jakarta, Bumi Aksari.

Suad Husnan dan Heidjrachman,

1990. Manajemen Personalia,

Edisi 4. Yogyakarta,

BPFE.

Sudjana, 1996. Metode Statistik.

Tarsito. Bandung.

Yawaludin,2004. Hubungan

Lingkungan Kerja dengan Prestasi

Kerja Karyawan

Pada PT. Hadji Kalla

Cabang Kendari. Skripsi Fakultas

Ekonomi Unhalu. 